\title{
Antioxidant Activity Assessment and Color Analysis of Skin from Different Peach Varieties Grown in South Carolina
}

\author{
Yueyuan Zhang, Inyee Han, Paul Dawson* \\ Department of Food, Nutrition and Packaging Sciences, Clemson University, Clemson, USA \\ Email: ${ }^{*}$ dawson@g.clemson.edu
}

Received 12 November 2014; revised 15 December 2014; accepted 28 December 2014

Copyright (C) 2015 by authors and Scientific Research Publishing Inc.

This work is licensed under the Creative Commons Attribution International License (CC BY). http://creativecommons.org/licenses/by/4.0/

(c) (i) Open Access

\begin{abstract}
Peach skin is a byproduct from the further processing of fresh peaches with the potential to be recovered and utilized as a natural antioxidant. Color analysis, phenolic content and antioxidant activity of peach skin from 13 varieties of peaches grown in South Carolina were determined. Color analysis indicated that Norman, Cary Mac, Ruby Prince and Flame Prince differed from other varieties of peaches. Antioxidant activity of peach skin extracts were evaluated by the total phenolics (TP), DPPH free radical scavenging (DPPH), ferric reducing antioxidant power (FRAP) and ferrous ion chelating (FIC) assays. The range of total phenolics content was 8.38 - 18.81 (gallic acid equivalent $\mathrm{mg} / \mathrm{g}$ dry weight). The total phenolic content was highly correlated to DPPH and FRAP activity in peaches ranging from $8-23 \mathrm{AE} / \mathrm{mg}$ and $5-12 \mathrm{AE} / \mathrm{mg}$, respectively. Three peach varieties with skins having the greatest antioxidant capacity were Red Globe, Scarlet Prince, and o’Henry.
\end{abstract}

\section{Keywords}

Peach Skin, Antioxidant, Total Phenolics, DPPH Assay, FRAP Assay

\section{Introduction}

Peach (Prunus persica) is one of the most popular fruits worldwide partly due to its good taste and nutrient composition [1] [2]. In the early 1970s, the annual per capita consumption of peaches in the US reached a peak of 13 pounds. By 2008, the annual consumption had dropped to 8.8 pounds per person [3]. In 2012, the US peach total production reached 978,260 tons while utilized production reached 965,420 tons [4]. South Carolina

\footnotetext{
"Corresponding author.
}

How to cite this paper: Zhang, Y.Y., Han, I. and Dawson, P. (2015) Antioxidant Activity Assessment and Color Analysis of Skin from Different Peach Varieties Grown in South Carolina. Food and Nutrition Sciences, 6, 18-28. 
is the second largest peach producing state in the United States. In 2012, South Carolina had a total of 17,000 acres of peach trees, total peach production reached 75,000 tons which was valued at over $\$ 74$ million. However for SC in 2012, unharvested peaches totaled 3700 tons and harvested but not sold peaches was 1050 tons ranking 1st and 2nd among all states, respectively [4]. Unutilized peaches could be further processed to recover valuable products including natural antioxidants. The possibility of extracting antioxidants from South Carolina peach skin byproducts has not been previously reported. Researchers have indicated that phenolic compounds play an important role in antioxidant activity of peaches [5]. Major phenolic compounds found in peaches include caffeic acid, chlorogenic acid, leucoanthocyanins, catechins and flavonols [5] [6]. Other antioxidants found in peaches include ascorbic acid and carotenoids; however, the content of ascorbic acid and carotenoids in peaches is relatively low [5]. Desmond and Daniele (2008) [7] pointed out that phenolic compounds were concentrated in peach skin.

Antioxidants act by several mechanisms; thus no one assay can capture the different modes of action and therefore several different methods are employed to measure antioxidant capacity. Since 1958, numerous in vitro antioxidant assays have been proposed including 2,2-diphenyl-1-picrylhydrazyl (DPPH) free radical scavenging assay [8], ferrous chelating capacity (FIC) [9], trolox equivalent antioxidant capacity assay (TEAC) [10], oxygen radical absorbing capacity (ORAC) [11], total radical trapping antioxidant parameter (TRAP) [12], ferric ion reducing antioxidant power assay (FRAP) [13], and 2,2'-azino-bis (3-ethylbenzothiazoline-6-sulphonic acid (ABTS) assay [14]. All of these antioxidant assays have been applied to test the antioxidant activity in vitro. Mostly, they are used to evaluate fruits, vegetables, plant extracts, beverages and nutritional supplements. Total phenolic assay, DPPH assay and FRAP assay are the most popular methods applied in research. The objective of this research was to determine the antioxidant (phenolic) content and antioxidant capacity of peach skin from various peach varieties grown in South Carolina.

\section{Materials and Methods}

\subsection{Materials}

2,2-diphenyl-1-picrylhydrazyl (DPPH), iron chloride hexahydrate $\left(\mathrm{FeCl}_{3} \cdot 6 \mathrm{H}_{2} \mathrm{O}\right)$, 3-(2-pyridyl)-5,6-diphenyl1,2,4-triazine-p,p'-disulfonic acid monosodium salt hydrate(ferrozine), Folin \& Ciocalteu's phenol reagent, sodium carbonate, iron chloride tetrahydrate $\left(\mathrm{FeCl}_{2} \cdot 4 \mathrm{H}_{2} \mathrm{O}\right)$ were purchased from Sigma-Aldrich. 2,4,6-tris(2pyrodyl)-s-triazine (TPTZ) was purchased from Sigma-Fluka. L-ascorbic acid, gallic acid were purchased from sigma life science. Ethyl alcohol (absolute, anhydrous, ACS/USP Grade) was purchased from Pharmco-AAPER. Acetic acid glacial was purchased from BDH. Hydrochloric acid solution certified $0.1 \mathrm{~N}$ was purchased from Fisher Scientific.

\subsection{Peaches}

13 cultivars of peaches from South Carolina, namely Summer Gold, Contender, July Flame, Scarlet Prince, Fire Prince, Cary Mac, Ruby Prince, Red Globe, Norman, Bounty, Early August Prince, Flame Prince, O’Henry at harvest stage between July 12 and August 15, 2013, were obtained from a SC producer. These varieties were chosen since these were the most popular during the peak growing season in this region of the Southeast US.

\subsection{Color Analysis}

Color of peach skin was measured on a model CR-400 chroma meter (Minolta Co. Ltd., Japan) by placing the colorimeter orifice directly on the peach surface prior to skin removal. Four peaches of each variety were randomly picked, four loacations on each peach were measured using the chroma meter. The color was expressed as CIE $1976 \mathrm{~L}^{*}, \mathrm{a}^{*}, \mathrm{~b}^{*}$, chroma $\left(\mathrm{C}^{*}\right)$, hue $\left(\mathrm{h}^{*}\right)$, with $\mathrm{L}^{*}$ representing the lightness of the color $\left(\mathrm{L}^{*}=0\right.$ yields black and $L^{*}=100$ indicates diffuse white), $a^{*}$ represents the redness to greeness of color (a* negative values indicate green while positive values indicate magenta), $b^{*}$ represents the yellowness to blueness of color $\left(b^{*}\right.$ negative values indicate blue and positive values indicate yellow). $\mathrm{C}^{*}$ represents the intensity or purity of color, $\mathrm{h}^{*}$ represents hue of color.

\subsection{Preparation of Peach Skin Samples}

Based on the size of different peach varieties, 10 to 15 peaches of each variety were picked for sampling. They 
were subdivided into 4 groups randomly. Peach skins were knife-peeled by hand and placed in marked sample bags and sealed. Those bags were frozen at $-80^{\circ} \mathrm{C}$ until analyzed. For each peach variety, four antioxidant assays were performed with one bag of peach skins each replication. In total four replications of each antioxidant assays were analyzed.

\subsection{Extraction Method}

Extraction procedures were based on Lim [15]. For one replication, one frozen sample bag of each variety was held at room temperature for 10 mins prior to extraction. After that, the remaining flesh in peach skin was scraped quickly and $10 \mathrm{~g}$ of peach skin was randomly taken from each sealed sample bag. Sample weights were recorded on a model B204-S College Monobloc analytical balance (Mettler Toledo, Toledo, OH). Moisture content was detected at the same time with a model HB43-S Mettler Toledo. Peach skins were blended for 6 seconds with $200 \mathrm{ml} 50 \%$ ethanol and then homogenized $30 \mathrm{~s}$. Homogenization was performed using a model PT 10/35 polytron with a model PCU 11 power control unit (Kinematica, Swizerland). The homogenized solution was placed in an ultrasound unit (model 5510R-DTH Ultrasonic unit. (Output $42 \mathrm{KHz} \pm 6 \%$, Bransonic Ultrasonics Corporation, Danbury, CT) and extracted for 30min at room temperature. Later, the extraction was centrifuged (Beckman Coulter Avanti J-26S XPI Centrifuge, Jersey city, NJ) at 15,008 g, $5^{\circ} \mathrm{C}$ for 15 minutes. In total, four replication of extraction were performed and supernatant was recovered carefully for antioxidant activity analysis.

\subsection{Antioxidant Activity Evaluation}

\subsubsection{Total Phenolics Content}

Total phenolic compounds in each peach skin extract were determined with Folin-Ciocalteu reagent according to the method of Singleton [16]. Gallic acid was used as a standard phenolic compound. Briefly, $0.04 \mathrm{ml}$ of each peach skin extract was diluted with distilled water $(3.16 \mathrm{ml}) .0 .2 \mathrm{ml}$ of Folin-Ciocalteu reagent was added and then mixed thoroughly. Within 8 minutes, $0.6 \mathrm{ml}$ of $\mathrm{Na}_{2} \mathrm{CO}_{3}$ (20\%) was added, mixed, and incubated $30 \mathrm{~min}$ in a $40^{\circ} \mathrm{C}$ water bath. The absorbance was measured at $765 \mathrm{~nm}$ with a spectrophotometer (Model 4001/4 Genesys 20 Thermo Fisher Scientific, Waltham, MA) Results were expressed as gallic acid equivalent (GAE) (mg gallic acid/g dried extract).

\subsubsection{DPPH Free Radical Scavenging Assay}

Radical scavenging activity of peach skin extract was measured according to the method of Molyneux [17]. Briefly, $0.4 \mathrm{ml}$ of each peach skin extract was added to $2 \mathrm{ml}$ of a DPPH solution ( $0.2 \mathrm{mM}$ in 50\% ethanol) and kept for $30 \mathrm{~min}$ at room temperature. The absorbance was measured at $517 \mathrm{~nm}$ with a spectrophotometer. (Model 4001/4 Genesys 20 spectrophotometer Thermo Fisher Scientific, Waltham, MA) L-Ascorbic acid (50 $\mu \mathrm{M}$ $400 \mu \mathrm{M}$ ) was used as a standard. Results were expressed as ascorbic acid equivalent (AE-DPPH) (mg ascorbic $\mathrm{acid} / \mathrm{g}$ dried extract).

\subsubsection{Ferric Reducing Antioxidant Power (FRAP) Assay}

Reducing power of peach skin extract was determined by FRAP assay described by Benzie and Strains [13]. Briefly, $300 \mathrm{mM}$ acetate buffer (pH 3.6), $10 \mathrm{mM}$ TPTZ in $40 \mathrm{mM} \mathrm{HCl}$, and $20 \mathrm{mM} \mathrm{FeCl} \cdot 6 \mathrm{H}_{2} \mathrm{O}$ were freshly prepared. pH was measured $\mathrm{pH}$ meter (by model S/N 004602, Orion Research Inc., city, state) Working FRAP reagent was prepared by mixing acetate buffer, $\mathrm{TPTZ}$ and $\mathrm{FeCl}_{3} \cdot 6 \mathrm{H}_{2} \mathrm{O}$ in the ratio of 10:1:1 at the time of use. $100 \mu \mathrm{l}$ of each peach skin extract was mixed with $3 \mathrm{ml}$ of working FRAP reagent and then kept at $37^{\circ} \mathrm{C}$ water bath for 4 minutes. The absorbance was measured at $593 \mathrm{~nm}$ with a spectrophotometer (model 4001/4 Genesys 20 spectrophotometer, Thermo fisher scientific, Waltham, MA) Ascorbic acid (100 $\mu \mathrm{M}-1000 \mu \mathrm{M})$ was used as a standard. The reducing power was expressed as ascorbic acid equivalent (AE-FRAP) (mg Ascorbic Acid/g dried extract).

\subsubsection{Ferrous Ion Chelating (FIC) Assay}

Ferrous ion-chelating potential of peach skin extract was determined according to the method of Gulcin [18]. Briefly, $1 \mathrm{ml}$ of peach skin extract was mixed with $0.2 \mathrm{ml}$ of $2 \mathrm{mM} \mathrm{FeCl}_{2}$. Then $2.4 \mathrm{ml} 50 \%$ ethanol was added. The reaction was initiated by the addition of $0.4 \mathrm{ml}$ of $5 \mathrm{mM}$ ferrozine. The mixture was allowed to sit at room 
temperature for 10 minutes before absorbance was measured at $562 \mathrm{~nm}$ with a spectrophotometer (Model 4001/4 Genesys 20 spectrophotometer Thermo fisher scientific, Waltham, MA). EDTA was used as positive control. The ability of the extract to chelate ferrous ion was calculated using the following equation

$$
\text { Chelating ability }(\% / \mathrm{mg} / \mathrm{ml})=\left[\frac{A_{0}-A_{1}}{A_{0}}\right] \times 100 \% / \text { Conc1 }
$$

where $A_{0}$ is the absorbance of the control, $A_{1}$ is the absorbance of peach skin sample or EDTA, Conc1 is the concentration of peach skin extracts.

\section{Statistical Analysis}

An analysis of variance (ANOVA) was conducted to compare the effect of peach varieties on peach skin color (L, a*, b*, hue, chroma), total phenolic content and antioxidant capacity (DPPH, FRAP, FIC), and when peach variety significantly $(\mathrm{P}<0.05)$ affected an individual peach property, the Tukey post hoc test was used to determine if there was a significant difference $(\mathrm{P}<0.05)$ among 13 varieties of peaches (SAS, 2011). The relationship of four antioxidant assays and peach skin color with phenolic content of peach skin was determined using the Pearson coefficient correlation.

\section{Results and Discussion}

\subsection{Color Analysis}

Lightness and hue values varied among the 13 varieties evaluated with Cary Mac, Ruby Prince, Flame Prince being significantly lighter $(\mathrm{P}<0.05)$ than all other varieties except for Contender (Figure 1$)$. Also, the value of lightness of Norman is significantly lower $(\mathrm{P}<0.05)$ than other peaches excluding July Flame and Summer Gold. The Norman variety was significantly lower $(\mathrm{P}<0.05)$ from other peaches in chroma value while other peaches had similar color purity (Figure 2). For hue value, Cary Mac and Flame Prince were also significantly higher $(\mathrm{P}<0.05)$ than all other peach varieties except Ruby Prince and Contender (Figure 3). In summary, Norman, Cary Mac, Ruby Prince and Flame Prince differed in several color parameters compared to other peach varieties (Table 1).

\subsection{Total Phenolic Content}

Phenolic content differed across the varieties of peaches tested. Among all the varieties, Red Globe had the highest phenolic content while Ruby Prince had the lowest mean content of phenolics (Figure 4). The order from greatest to lowest average phenolic content was Red Globe, Scarlet Prince, O’Henry, Bounty, Fire Prince, Norman, July Flame, Cary Mac, Summer Gold, Flame Prince, Contender, Early August Prince, Ruby Prince. Red Globe had a significantly greater $(\mathrm{P}<0.05)$ phenolic content than July Flame, Cary Mac, Summer Gold, Flame Prince, Contender, Early August Prince and Ruby Prince while the Scarlet Prince variety had greater $(\mathrm{P}<$ 0.05) phenolic content than Early August Prince and Ruby Prince. Red Globe and Summer Gold varieties

\section{Color Analysis (Lightness)}

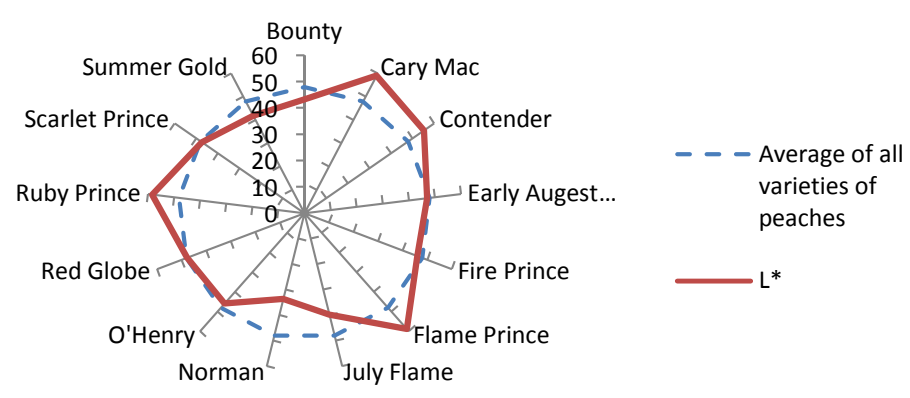

Figure 1. Color analysis $\left(\mathrm{L}^{*}\right)$ of 13 cultivars of peaches. 


\section{Color Analysis (Color Purity)}

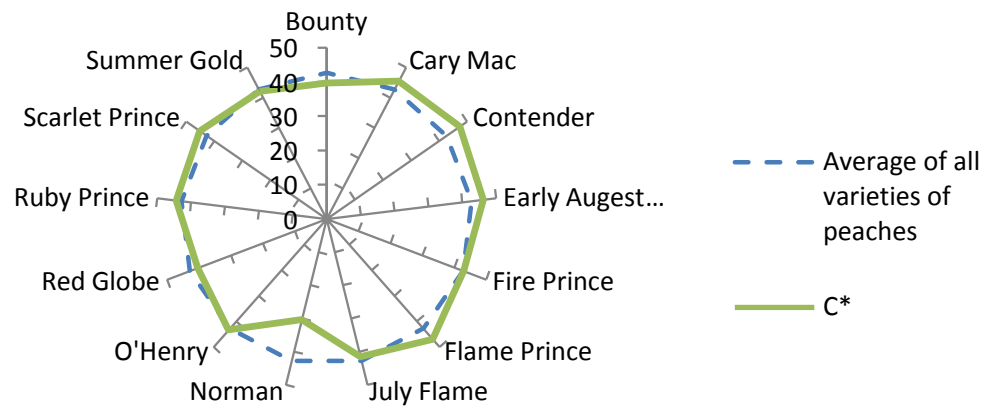

Figure 2. Color analysis $\left(C^{*}\right)$ of 13 cultivars of peaches.

\section{Color Analysis (Hue)}

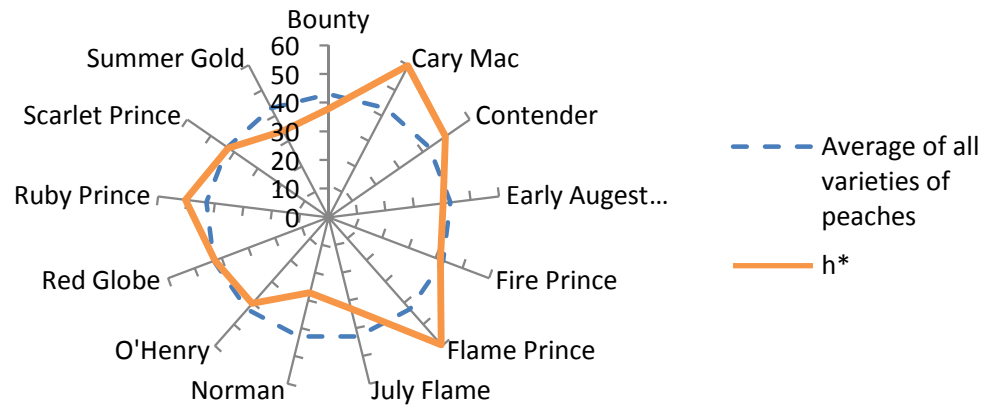

Figure 3. Color analysis (hue) of 13 varieties of peaches.

Total Phenolics Content

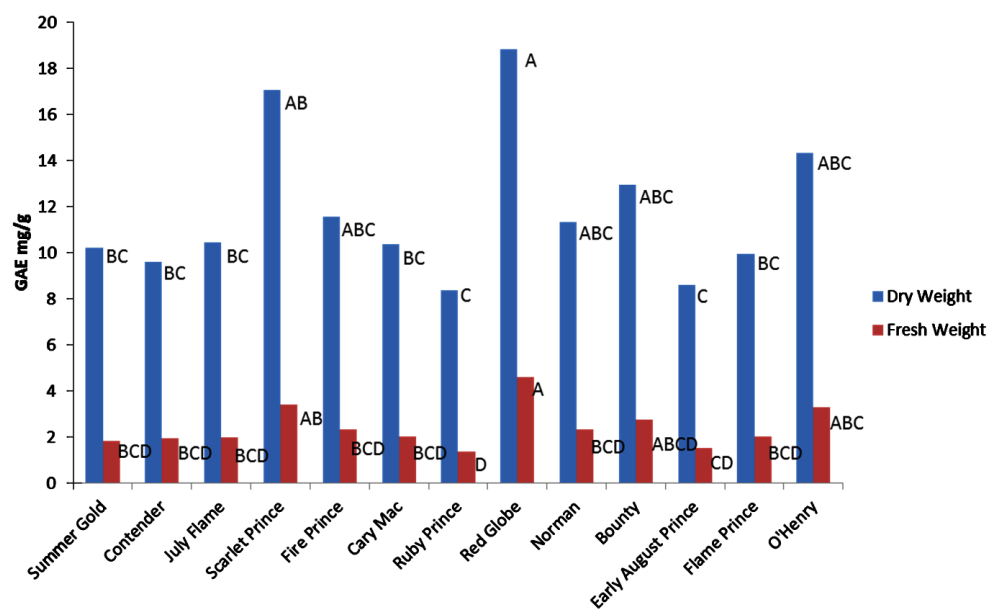

Figure 4. Antioxidant activity of total phenolics assay A-D means within the same color bar having the same subscript are not significantly different $(\mathrm{P}>$ 0.05). Standard error $(\mathrm{SE})=1.54, \mathrm{n}=12$.

had a large variation while the Scarlet Prince variety had both a high phenolic content and a relatively small range of variation in phenolic content (Figure 5). 
Table 1. Color analysis of 13 cultivars of peach skins.

\begin{tabular}{|c|c|c|c|c|c|c|c|c|c|c|}
\hline \multirow{2}{*}{$\begin{array}{c}\text { Color } \\
\text { Cultivar }\end{array}$} & \multicolumn{2}{|c|}{$\mathbf{L}^{*}$} & \multicolumn{2}{|c|}{$\mathbf{C}^{*}$} & \multicolumn{2}{|c|}{$\mathbf{h}^{*}$} & \multicolumn{2}{|c|}{$a^{*}$} & \multicolumn{2}{|c|}{$\mathbf{b}^{*}$} \\
\hline & $\begin{array}{l}\text { Estimate } \\
\text { means }\end{array}$ & $\begin{array}{l}\text { Standard } \\
\text { deviation }\end{array}$ & $\begin{array}{l}\text { Estimate } \\
\text { means }\end{array}$ & $\begin{array}{l}\text { Standard } \\
\text { deviation }\end{array}$ & $\begin{array}{l}\text { Estimate } \\
\text { means }\end{array}$ & $\begin{array}{l}\text { Standard } \\
\text { deviation }\end{array}$ & $\begin{array}{l}\text { Estimate } \\
\text { means }\end{array}$ & $\begin{array}{l}\text { Standard } \\
\text { deviation }\end{array}$ & $\begin{array}{c}\text { Estimate } \\
\text { means }\end{array}$ & $\begin{array}{l}\text { Standard } \\
\text { deviation }\end{array}$ \\
\hline Bounty & $43.32^{\mathrm{C}}$ & 7.06 & $39.69^{\mathrm{B}}$ & 7.72 & $37.76^{\mathrm{BCD}}$ & 12.03 & $30.24^{\mathrm{ABC}}$ & 6.40 & $24.48^{\mathrm{DEF}}$ & 9.12 \\
\hline Cary Mac & $59.07^{\mathrm{A}}$ & 4.97 & $45.49^{\mathrm{AB}}$ & 2.16 & $59.82^{\mathrm{A}}$ & 11.14 & $22.48^{\mathrm{D}}$ & 7.74 & $38.61^{\mathrm{AB}}$ & 4.77 \\
\hline Contender & $55.30^{\mathrm{AB}}$ & 6.40 & $47.52^{\mathrm{A}}$ & 3.40 & $49.72^{\mathrm{AB}}$ & 9.66 & $30.08^{\mathrm{ABC}}$ & 5.19 & $36.00^{\mathrm{ABC}}$ & 6.82 \\
\hline $\begin{array}{c}\text { Early August } \\
\text { Prince }\end{array}$ & $47.03^{\mathrm{BC}}$ & 4.22 & $46.27^{\mathrm{AB}}$ & 3.75 & $40.37^{\mathrm{BCD}}$ & 4.66 & $35.05^{\mathrm{A}}$ & 2.80 & $30.00^{\mathrm{ABCDE}}$ & 4.41 \\
\hline Fire Prince & $45.98^{\mathrm{BC}}$ & 9.19 & $42.92^{\mathrm{AB}}$ & 5.76 & $41.93^{\mathrm{BC}}$ & 13.69 & $30.43^{\mathrm{ABC}}$ & 5.58 & $28.62^{\mathrm{BCDE}}$ & 10.28 \\
\hline Flame Prince & $58.83^{\mathrm{A}}$ & 8.34 & $46.92^{\mathrm{AB}}$ & 3.98 & $59.58^{\mathrm{A}}$ & 13.14 & $22.59^{\mathrm{D}}$ & 6.75 & $39.92^{\mathrm{A}}$ & 8.62 \\
\hline July Flame & $39.73^{\mathrm{CD}}$ & 4.23 & $41.47^{\mathrm{AB}}$ & 5.39 & $32.98^{\mathrm{CD}}$ & 5.74 & $34.45^{\mathrm{AB}}$ & 3.66 & $22.73^{\mathrm{EF}}$ & 5.76 \\
\hline Norman & $33.56^{\mathrm{D}}$ & 5.77 & $30.26^{\mathrm{C}}$ & 8.82 & $27.11^{\mathrm{D}}$ & 6.44 & $26.41^{\mathrm{CD}}$ & 6.61 & $14.43^{\mathrm{F}}$ & 6.69 \\
\hline O’Henry & $45.89^{\mathrm{BC}}$ & 8.72 & $43.33^{\mathrm{AB}}$ & 4.83 & $40.18^{\mathrm{BCD}}$ & 11.50 & $32.04^{\mathrm{ABC}}$ & 3.99 & $27.95^{\mathrm{CDE}}$ & 9.03 \\
\hline Red Globe & $47.73^{\mathrm{BC}}$ & 13.72 & $40.33^{\mathrm{AB}}$ & 9.69 & $42.36^{\mathrm{BC}}$ & 19.58 & $26.39^{\mathrm{CD}}$ & 6.68 & $27.62^{\mathrm{CDE}}$ & 15.07 \\
\hline Ruby Prince & $58.30^{A}$ & 7.38 & $44.31^{\mathrm{AB}}$ & 2.83 & $50.27^{\mathrm{AB}}$ & 11.05 & $27.63^{\mathrm{BCD}}$ & 5.94 & $33.67^{\mathrm{ABCD}}$ & 6.56 \\
\hline Scarlet Prince & $47.48^{\mathrm{BC}}$ & 8.13 & $45.10^{\mathrm{AB}}$ & 6.61 & $42.55^{\mathrm{BC}}$ & 11.52 & $32.11^{\mathrm{ABC}}$ & 5.78 & $30.59^{\mathrm{ABCDE}}$ & 9.05 \\
\hline Summer Gold & $41.81^{\mathrm{CD}}$ & 7.09 & $42.10^{\mathrm{AB}}$ & 7.40 & $34.05^{\mathrm{CD}}$ & 8.55 & $34.03^{\mathrm{AB}}$ & 4.35 & $24.10^{\mathrm{DEF}}$ & 8.45 \\
\hline
\end{tabular}

A-E mean within the same column with the same subscript are not significantly different $(\mathrm{P}>0.05) . \mathrm{n}=16$.

\subsection{DPPH Assay}

Ascorbic acid was used as the standard for the DPPH assay thus results were expressed as ascorbic acid equivalent (AE). The Red Globe variety had the greatest radical scavenging activity (Figure 6). The order from highest to radical scavenging activity was Red Globe, O’Henry, Scarlet Prince, Bounty, Norman, Flame Prince, Fire Prince, July Flame, Cary Mac, Summer Gold, Contender, Early August Prince, Ruby Prince. Red Globe peaches were not significantly different $(\mathrm{P}>0.05)$ from O’Henry, Scarlet Prince, Bounty and Norman but had greater (P $<0.05)$ radical scavenging activity than other varieties. O’Henry had greater $(\mathrm{P}<0.05)$ scavenging activity than Early August Prince, Contender and Ruby Prince. Box and whisker plot revealed that Red Globe and O’Henry peach samples had more variation than others and that Scarlet Prince (as with phenolic content) had low variation and relatively high scavenging activity (Figure 7).

\subsection{FRAP Assay}

Ascorbic acid was also used as the standard reference for FRAP analysis therefore results were expressed as ascorbic acid equivalents (AE). The order from highest to least reducing ability of peach varieties was Red Globe, Scarlet Prince, Bounty, Norman, O’Henry, July Flame, Fire Prince, Summer Gold, Early August Prince, Cary Mac, Flame Prince, Contender, Ruby Prince (Figure 8). Red Globe had significantly $(\mathrm{P}<0.05)$ more reducing ability than Early August Prince, Cary Mac, Flame Prince, Contender and Ruby Prince. Ruby Prince was lower $(\mathrm{P}<0.05)$ in FRAP AE than O' Henry, Norman, Bounty, Scarlet Prince and Red Globe. Box whisker distribution of FRAP assay showed that the Red Globe peach variety had the most variation (Figure 9).

\subsection{FIC Assay}

Results of ferrous ion chelating (FIC) assay differed from the other antioxidant assays which may be due to the fact that FIC assay measures chelating ability, a different mode of antioxidant action compared to other assays used. The order of highest to lowest chelating ability was Early August Prince, Ruby Prince, Norman, Flame Prince, Summer Gold, Contender, Cary Mac, Bounty, July Flame, Scarlet Prince, Fire Prince, Red Globe, 


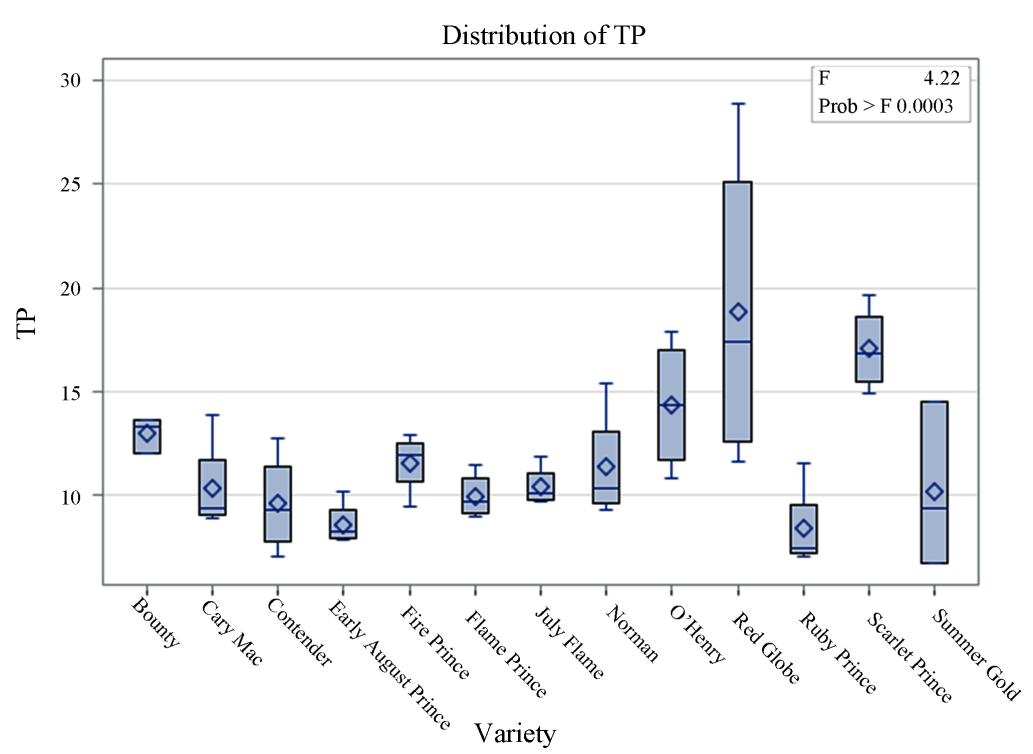

Figure 5. Box and whisker of total phenolics assay (dry weight).

DPPH Assay

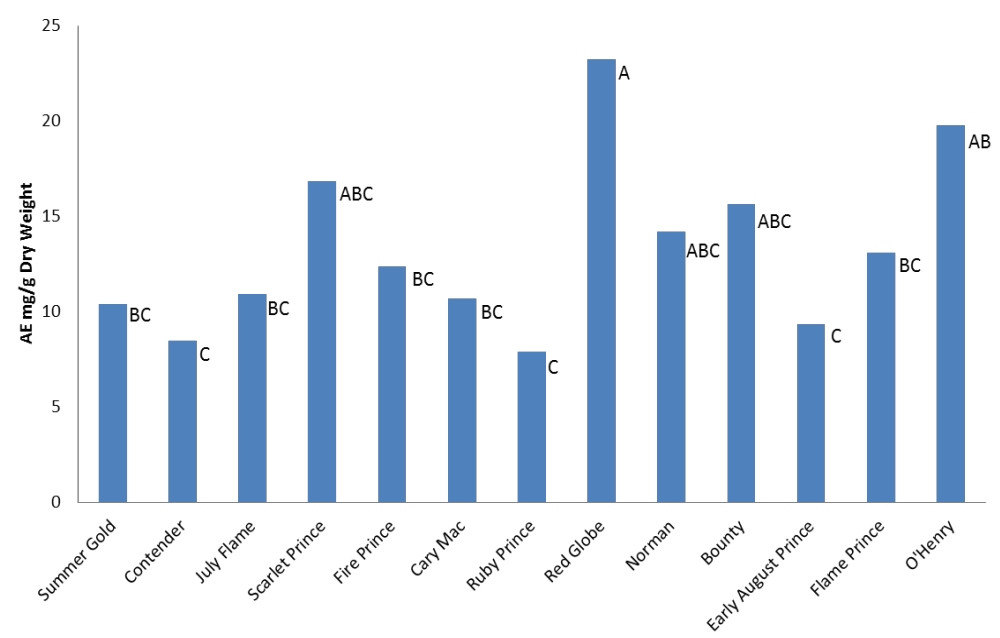

Figure 6. Antioxidant activity of DPPH assay A-C means with the same subscript are not significantly different $(\mathrm{P}>0.05) . \mathrm{SE}=1.94, \mathrm{n}=12$.

O'Henry (Figure 10). Early August Prince was significantly greater $(\mathrm{P}<0.05)$ than July Flame, Scarlet Prince, Fire Prince, Red Globe and O’Henry. O’Henry had significantly lower $(\mathrm{P}<0.05)$ chelating ability than Early August Prince, Ruby Prince, Flame Prince and Norman. For chelating ability, Ruby Prince peaches had the largest variation while Bounty, Flame Prince, Red Globe and Scarlet Prince varied the least (Figure 11).

\subsection{Correlation of Four Antioxidant Assays}

There is no one assay that measures all aspects of antioxidant capacity. Therefore, antioxidant assays based on different modes of action were performed to evaluate overall antioxidant capacity. Correlation of different antioxidant assays was performed to verify the relationship between assays in evaluating different peach varieties. $\mathrm{P}$ value of all the Pearson correlation was less than 0.05 . TP and DPPH assays were the most closely correlated with an $\mathrm{R}$ value of 0.92 . Table 2 shows that total phenolics, DPPH and FRAP assays are all positively and significantly correlated while the FIC assay negatively correlated to total phenolics and DPPH and in non-significantly related to the FRAP assay. 


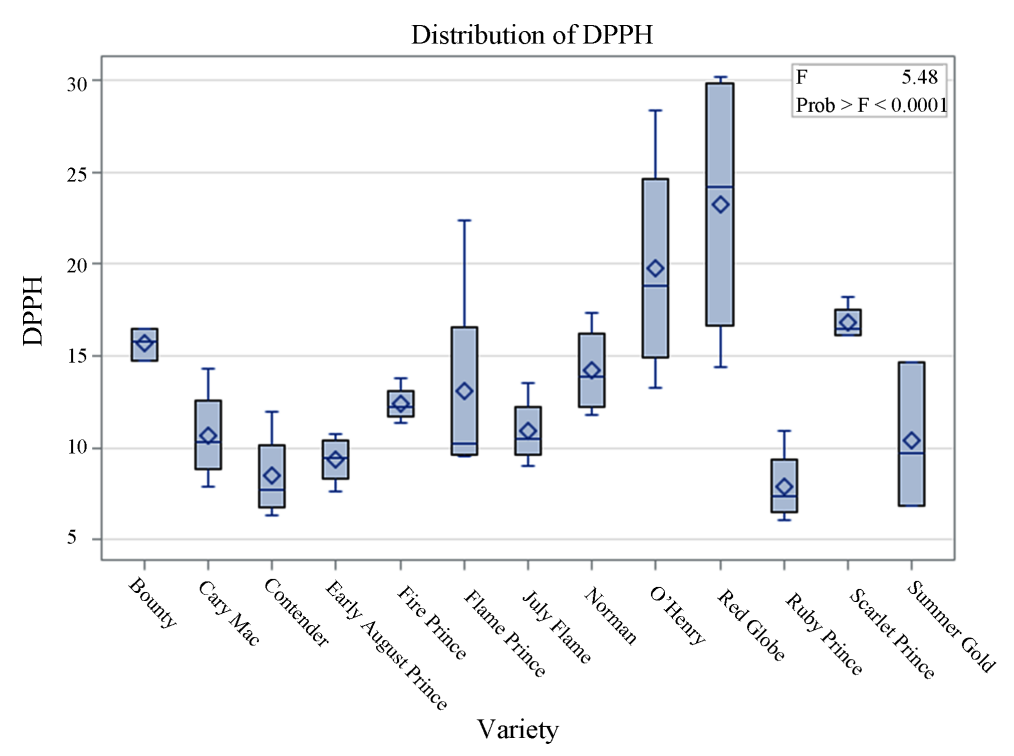

Figure 7. Box and whisker plot of DPPH assay.

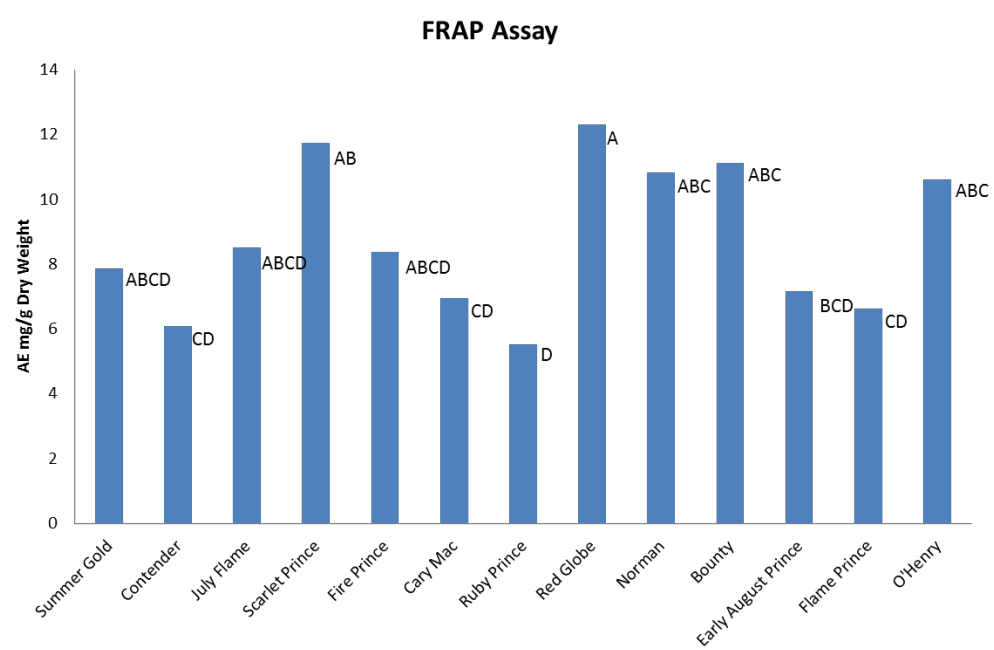

Figure 8. Antioxidant activity of FRAP assay A-D means with the same subscript are not significantly different $(\mathrm{P}>0.05)$. $\mathrm{SE}=0.96, \mathrm{n}=12$.

Table 2. Correlation of four antioxidant assays.

\begin{tabular}{|c|c|c|c|c|}
\hline \multicolumn{5}{|c|}{ Pearson correlation coefficients (R), $\mathrm{N}=13$} \\
\hline \multicolumn{5}{|c|}{ Prob $>|r|$ under $\mathrm{H}_{0}:$ Rho $=0$} \\
\hline & & DPPH assay & FRAP assay & FIC assay \\
\hline \multirow{2}{*}{ TP assay } & $\mathrm{R}$ & 0.92 & 0.88 & -0.76 \\
\hline & $\mathrm{P}$ & $<0.0001$ & $<0.0001$ & 0.0024 \\
\hline \multirow{2}{*}{ DPPH assay } & $\mathrm{R}$ & & 0.87 & -0.69 \\
\hline & $\mathrm{P}$ & & $<0.0001$ & 0.0084 \\
\hline \multirow{2}{*}{ FRAP assay } & $\mathrm{R}$ & & & -0.66 \\
\hline & $\mathrm{P}$ & & & 0.014 \\
\hline
\end{tabular}




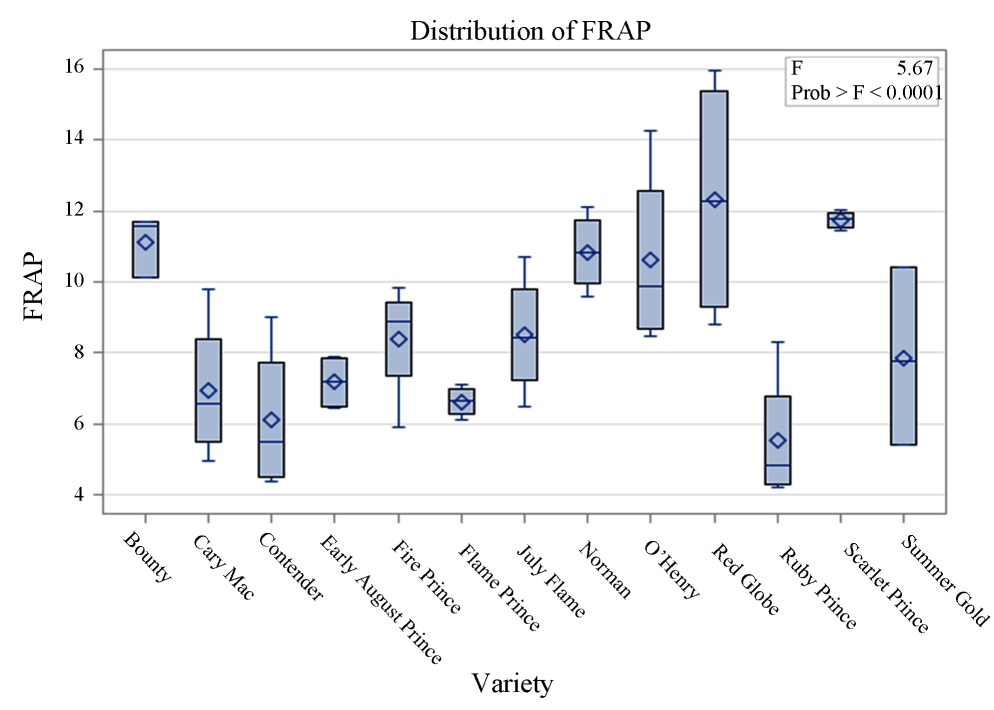

Figure 9. Box and whisker plot of FRAP assay.

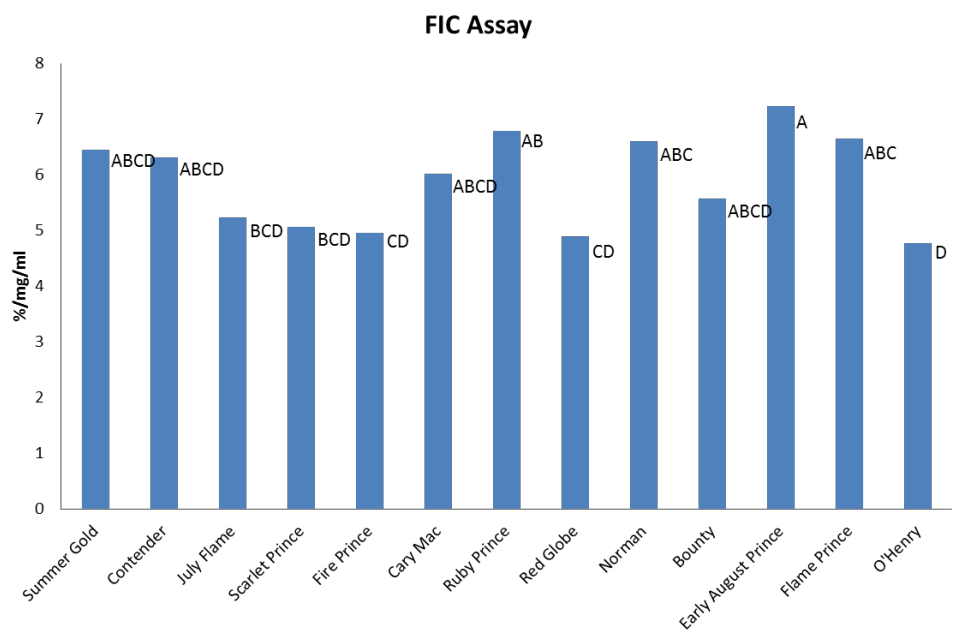

Figure 10. Antioxidant activity of FIC assay A-D means with the same subscript are not significantly different $(\mathrm{P}>0.05)$. $\mathrm{SE}=0.36, \mathrm{n}=12$.

\subsection{Correlation of Color and Total Phenolic Content}

Correlation of color and total phenolic content was performed to determine the relationship of color and phenolic content. $\mathrm{P}$ values of all Pearson correlations were greater than 0.05 and $\mathrm{R}$ values were all close to 0 (Table 3 ) therefore, peach skin color measurements were not significantly correlated to total phenolic content of peaches.

The total phenolic content and antioxidant activity of peach skin were affected by peach cultivar. The range of total phenolics content was 8.38 - 18.81 (Gallic Acid Equivalent mg/g dry weight). Babbar [19] reported total phenolics content of six fruit residues which are kinnow seed $3.68 \mathrm{mg}$ GAE/g dry weight, kinnow peel $17.5 \mathrm{mg}$ GAE/g dry weight, litchi seed $17.9 \mathrm{mg}$ GAE/g dry weight, litchi pericarp $24.6 \mathrm{mg}$ GAE/g dry weight, grape seed $37.4 \mathrm{mg}$ GAE/g dry weight, banana peel $3.8 \mathrm{mg}$ GAE/g dry weight. Though the total phenolic content of peach skins were lower than grape seed, all the peach skins from different varieties were higher than kinnow seed and banana peel. Some varieties like Red Globe and Scarlet prince were similar to kinnow peel and litchi seed. In general, peach skin possessed a high antioxidant capacity. The order of antioxidant capacity strength of TP, DPPH and FRAP assays followed a similar trend due to cultivar while the result of FIC assay results did not match the other assays.

Previous research has showed that total phenolic content of O’Henry peach skin evaluated by HPLC-DAD 


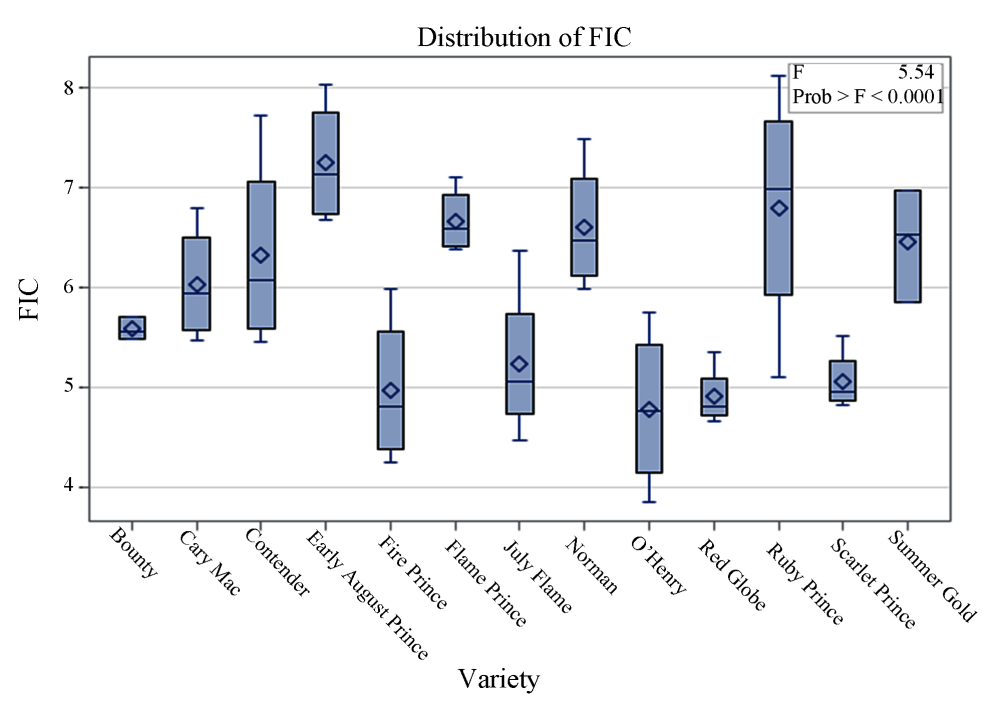

Figure 11. Box and whisker plot of FIC assay.

Table 3. Correlation of color and total phenolic content.

\begin{tabular}{|c|c|c|c|c|c|c|}
\hline \multicolumn{7}{|c|}{ Pearson correlation coefficients (R), $\mathrm{N}=13$} \\
\hline \multicolumn{7}{|c|}{ Prob $>|\mathrm{r}|$ under $\mathrm{H}_{0}:$ Rho $=0$} \\
\hline \multirow{3}{*}{ Total phenolic } & & $\mathrm{L}^{*}$ & $a^{*}$ & $b^{*}$ & $\mathrm{C}^{*}$ & $\mathrm{~h}^{*}$ \\
\hline & $\mathrm{R}$ & -0.2365 & -0.0212 & -0.2045 & -0.2234 & -0.19 \\
\hline & $\mathrm{P}$ & 0.4365 & 0.9451 & 0.5027 & 0.4632 & 0.5341 \\
\hline
\end{tabular}

method was $120.2 \mathrm{mg} / 100 \mathrm{~g}$ fresh weight [20]. In the current study, total phenolics content (Gallic acid equivalent) of O’Henry was $328.7 \mathrm{mg} / 100 \mathrm{~g}$ fresh weight. Since total phenolic content was expressed directly in previous research but expressed indirectly as Gallic acid equivalent in current research, they cannot be compared directly. Factors which may influence the total phenolic contents of peaches included growing environment, weather conditions, time of harvest and soil conditions.

Correlations among TP, DPPH and FRAP assays were all high while the correlation coefficient of FIC assay to the other assays was not as high. This is case since the FIC assay measures chelating ability while the other assays measure phenolics and reducing or radical scavenging which are closely related to phenolic structure. While both DPPH assay and FRAP assay measure reducing reactions, the antioxidant capacity evaluated of DPPH assay was generally higher than FRAP assay. DPPH assay is based on the transfer of hydrogen atom, while FRAP assay depends on the electron transfer, particularly reducing of Fe(III) [21]. Not all antioxidants can reduce the Fe(III), and this could be the reason the FRAP assay gave a lower value than the DPPH assay.

\section{Conclusion}

Since peach variety affected antioxidant capacity and phenolic content of skin, use of skin to produce a natural antioxidant additive would require quality control to ensure consistent antioxidant product. Further studies may include HPLC analysis of peach skin components and antioxidant activity test in vivo. Also, since peach skin extracts have strong antioxidant activity, production of a natural additive for use as a food additive could be an economic benefit to the peach industry.

\section{References}

[1] Block, G., Patterson, B. and Subar, A. (1992) Fruit, Vegetables and Cancer Prevention: A Review of the Epidemiological Evidence. Nutrition and Cancer, 18, 1-29. http://dx.doi.org/10.1080/01635589209514201

[2] Ness, A.R. and Powles, J.W. (1997) Fruits and Vegetables and Cardiovascular Disease: A Review. International Jour- 
nal of Epidemiology, 26, 1-13. http://dx.doi.org/10.1093/ije/26.1.1

[3] Brunke, H., Chang, M., Huntrods, D. and McKee, G. (2013) Peach Profile. Agriculture Marketing Resource Center (AgMRC). http://www.agmrc.org/commodities_products/fruits/peach-profile/

[4] USDA (2013) Noncitrus Fruits and Nuts 2012 Preliminary Summary. http://www.nass.usda.gov/Publications/Todays_Reports/reports/fnutsb14.pdf

[5] Francisco, A.T., María, I.G., Paedar, C., Andrew, L.W., Betty, H.P. and Adel, A.K. (2001) HPLC-DAD-ESIMS Analysis of Phenolic Compounds in Nectarines, Peaches, and Plums. Journal of Agriculture and Food Chemistry, 49, 47484760. http://dx.doi.org/10.1021/jf0104681

[6] Campbell, O.E. and Padilla-Zakour, O.I. (2013) Phenolic and Carotenoid Composition of Canned Peaches (Prunus persica) and Apricots (Prunus armeniaca) as Affected by Variety and Peeling. Food Research International, 54, 448455. http://dx.doi.org/10.1016/j.foodres.2013.07.016

[7] Desmond, R.L. and Daniele, B. (2008) The Peach Botany, Production and Uses. In: Crisosto, C.H. and Valero, D., Eds., Harvesting and Postharvest Handling of Peaches for the Fresh Market, CAB International, 575-594.

[8] Kurechi, T., Kikugawa, K. and Kato, T. (1980) Studies on the Antioxidants Hydrogen Donating Capability of Antioxidants to 2,2-Diphenyl-1-Picrylhydrazyl. Chemical and Pharmaceutical Bulletin, 28, 2089-2093.

http://dx.doi.org/10.1248/cpb.28.2089

[9] Decker, E.A. and Welch, B. (1990) Role of Ferritin as a Lipid Oxidation Catalyst in Muscle Food. Journal of Agriculture and Food Chemistry, 38, 674-677. http://dx.doi.org/10.1021/jf00093a019

[10] Miller, N.J., Rice-Evans, C.A., Davies, M.J., Gopinathan, V. and Milner, A. (1993) A Novel Method for Measuring Antioxidant Capacity and Its Application to Monitoring Antioxidant Status in Premature Neonates. Clinical Science, 84, 407-412.

[11] Cao, G., Alessio, H.M. and Cutler, R.G. (1993) Oxygen-Radical Absorbance Capacity Assay for Antioxidants. Free Radical Biology and Medicine, 14, 303-311. http://dx.doi.org/10.1016/0891-5849(93)90027-R

[12] Lissi, E., Salim-Hanna, M., Pascual, C. and del Castillo, M.D. (1995) Evaluation of Total Antioxidant Potential (TRAP) and Total Antioxidant Reactivity from Luminol-Enhanced Chemiluminescence Measurements. Free Radical Biology and Medicine, 18, 153-158. http://dx.doi.org/10.1016/0891-5849(94)00117-3

[13] Benzie, I.F.F. and Strain, J.J. (1996) The Ferric Reducing Ability of Plasma (FRAP) as a Measure of "Antioxidant Power”: The FRAP Assay. Analytical Biochemistry, 239, 70-76. http://dx.doi.org/10.1006/abio.1996.0292

[14] Re, R., Pellegrini, N., Proteggente, A., Pannala, A., Yang, M. and Rice-Evans, C. (1999) Antioxidant Activity Applying an Improved ABTS Radical Cation Decolorization Assay. Free Radical Biology and Medicine, 26, 1231-1237. http://dx.doi.org/10.1016/S0891-5849(98)00315-3

[15] Lim, Y.Y., Lim, T.T. and Tee, J.J. (2007) Antioxidant Properties of Several Tropical Fruits: A Comparative Study. Food Chemistry, 103, 1003-1008. http://dx.doi.org/10.1016/j.foodchem.2006.08.038

[16] Singleton, V.L., Orthofer, R. and Lamuela-Raventos, R.M. (1999) Analysis of Total Phenols and Other Oxidation Substrates and Antioxidants by Means of Folin-Ciocalteu Reagent. Methods in Enzymology, 299, 152-178. http://dx.doi.org/10.1016/S0076-6879(99)99017-1

[17] Molyneux, P. (2004) The Use of the Stable Free Radical Diphenylpicrylhydrazyl (DPPH) for Estimating Antioxidant Activity. Songklanakarin Journal of Science and Technology, 26, 211-219.

[18] Gulcin, I., Tel, A.Z. and Kirecci, E. (2008) Antioxidant, Antimicrobial, Antifungal, and Antiradical Activities of Cyclotrichium niveum (BOISS) Manden and Scheng. International Journal of Food Properties, 11, 450-471. http://dx.doi.org/10.1080/10942910701567364

[19] Babbar, N., Oberoi, H.S., Uppal, D.S. and Patil, R.T. (2011) Total Phenolic Content and Antioxidant Capacity of Extracts Obtained from Six Important Fruit Residues. Food Research International, 44, 391-396. http://dx.doi.org/10.1016/j.foodres.2010.10.001

[20] Maria, I.G., Francisco, A.T., Betty, H. and Adel, A.K. (2002) Antioxidant Capacities, Phenolic Compounds, Carotenoids, and Vitamin C Contents of Nectarine, Peach, and Plum Cultivars from California. Journal of Agriculture and Food Chemistry, 50, 4976-4982. http://dx.doi.org/10.1021/jf020136b

[21] Huang, D., Qu, B. and Prior, R.L. (2005) The Chemistry behind Antioxidant Capacity Assays. Journal of Agriculture and Food Chemistry, 53, 1841-1856. http://dx.doi.org/10.1021/jf030723c 
Scientific Research Publishing (SCIRP) is one of the largest Open Access journal publishers. It is currently publishing more than 200 open access, online, peer-reviewed journals covering a wide range of academic disciplines. SCIRP serves the worldwide academic communities and contributes to the progress and application of science with its publication.

Other selected journals from SCIRP are listed as below. Submit your manuscript to us via either submit@scirp.org or Online Submission Portal.
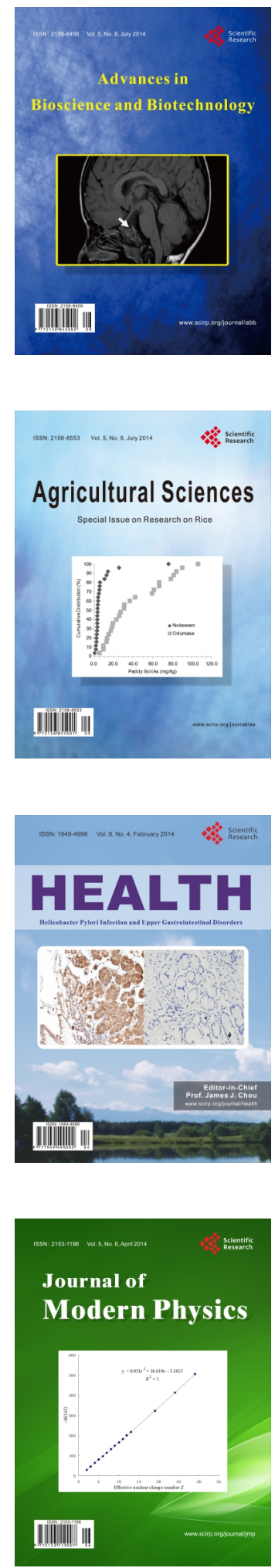
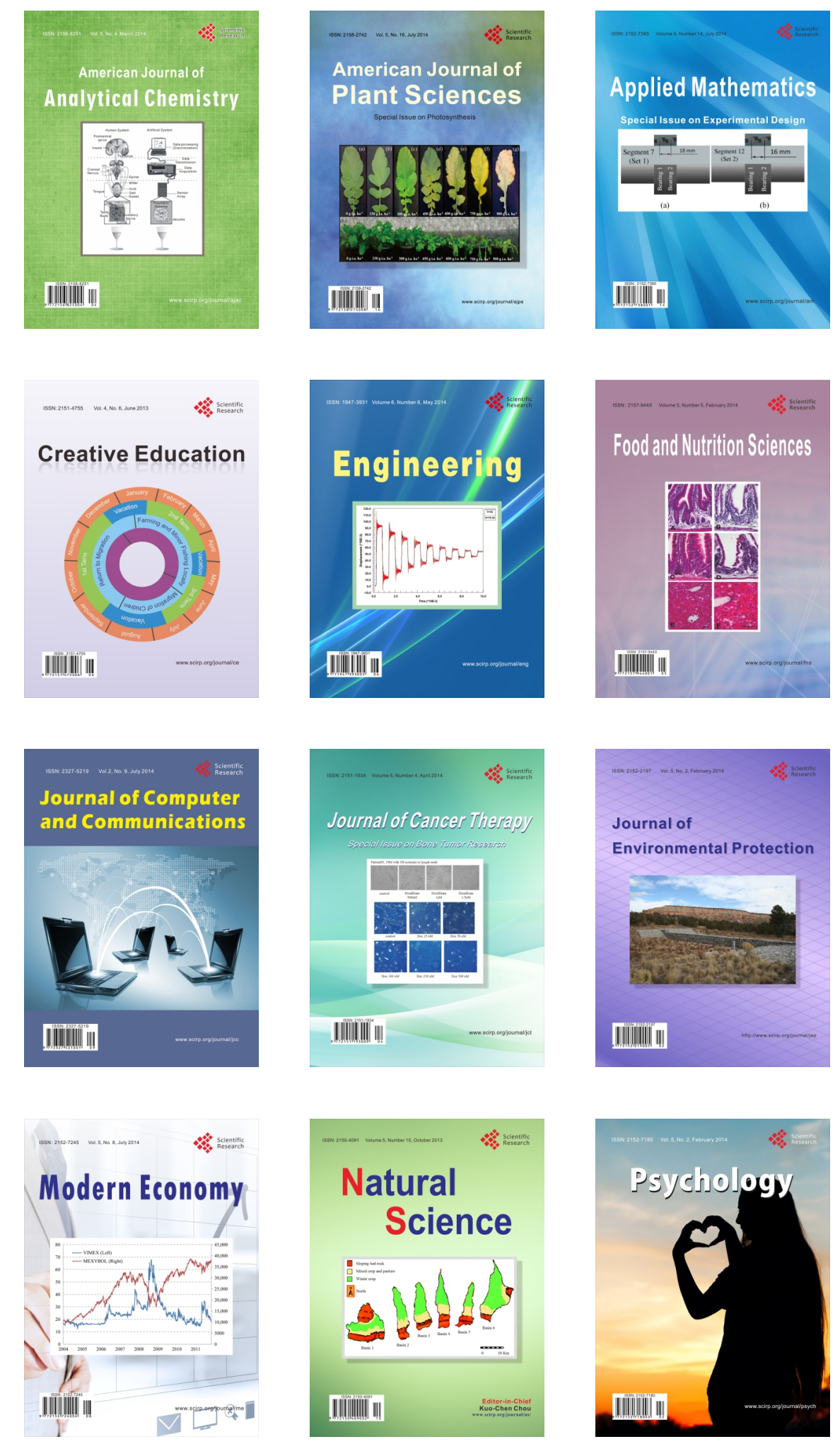